\title{
The Transmission of the Orthodox Spiritual Tradition in Russian Culture and Beyond
}

\author{
Svetlana Tokareva \\ Department of Philosophy \\ Law Faculty \\ Volgograd State University \\ Volgograd, Russia 400062 \\ E-mail: svet-tok2008@yandex.ru \\ E-mail: tokareva@volsu.ru
}

\author{
Iliya Dikarev \\ Law Faculty \\ Volgograd State University \\ Volgograd, Russia 400062 \\ E-mail: dikarew@mail.ru.
}

\begin{abstract}
The authors of the article review the channels of transmitting the Orthodox tradition. The peculiarities of maintaining the Orthodox tradition in the Russian and Western cultures are being analyzed with special attention given to speech practices with church-religious genres and fiction being of key importance. The authors analyze the established link between Russian literature and the Orthodox tradition. The influence of religious globalization and religious syncretism on the transmission of the Orthodox tradition is revealed.
\end{abstract}

Keywords-religious tradition; Orthodoxy; spirituality; Hesychasm; fiction

\section{INTRODUCTION}

Social and humanitarian knowledge in contemporary Russian society is experiencing a kind of "religious Renaissance" rooted in the post-Soviet era. This Renaissance of a kind draws the attention to a number of researchers. Since speech practices are among the major channels used for cultural and religious transmission, the interest in this issue also touches the fields of language and communication, including linguistics, literary studies, and philosophy.

The transmission of the Orthodox tradition occurs both inside and outside the Orthodox Russian World. In the former case, the preservation of tradition is carried out in its entirety and includes sacred and ritual elements, institutional forms and patterns of religious behavior, as well as spiritual practices of the "living" religious experience. The transmission of the Orthodox tradition uses a system of speech practices with the produced texts being "a speech correlate of socio-cultural practices of actual construction and transmission of tradition" [1]. The peculiarity of the Orthodox sphere of concepts is reflected in religious literature and journalism, sermons, fiction, folklore, and everyday linguistic consciousness. Within each genre, the forms of statements are determined by the speaker's intentions, draw on the cultural traditions, consider the connotations and implicit background knowledge of the communicators and their social, cultural and psychological characteristics. At the same time, each of the aforementioned types of speech practices boasts genre-defining factors of distorting the Orthodox tradition. Despite this, these types provide an understanding of the Orthodox meanings and values, shared by all the members of the cultural community, and prevent the fragmentation of the living space of the bearers of the Orthodox tradition.

The transmission of the Orthodox tradition in a culturally alien environment experiences a destructive influence of religious globalization, lacking everyday speech practices and folklore, therefore, the transmission is carried out largely through fiction and sermons with sermon being the leading genre of religious discourse, providing verbal registration of typical situations of social interactions. A sermon is an influencing speech, based on a long historical tradition and aimed at clarifying the doctrinal content and instructing the believers. In modern conditions, sermons may be spread not only through the direct interaction of the communicators but also through media due to the expansion of indirect communication and the replacement of book culture with electronic transmission of information.

Despite sermon and fiction sharing some communicative features (e.g., high requirements for the personality of the preacher and the writer, perceived as spiritual mentors), a sermon demands a specific set of communicators, while fiction is designed for the widest audience possible. The sermon's edifying function is supported by its status character and the obligatory presence in its structure the informative and narrative parts accompanied by the interpretation [2]. Since the genre of a sermon is institutional, there are pre-set communicators and communicative environment, material and communicative sphere, text corpus and non-vernal inclusions. Such substantiation allows limiting the destructive influence of the alien cultural environment (including the secular one)

On the contrary, artistic expression offers an opportunity for assimilation of spiritual traditions in their native (i.e. producing) culture and beyond it, in the alien environment lacking the necessary connotations. A writer describes and specializes religious practice, shaping it and weaving into the plot and the lives of the characters, into their personality. Thanks to this technique and to the reproduction of the religious practices in a cultural context of the works of art, a 
reader experiences and assimilates the embedded symbolic values.

\section{TRANSMISSION OF THE ORTHODOX TRADITION IN RUSSIAN CULTURE}

The most important channel for the transmission of the Orthodox traditions in Russian culture is Russian literature, which has always been heavily invested in the spiritual life of man. Russian literature originally emerged as a spiritual and religious one. The 17 th-century attempts to isolate Russian culture from faith didn't lead to profound changes in the culture's core, and the literature retained its connection with Orthodoxy and Evangelical preaching in all subsequent periods of its development including the Soviet one [3]. The form and extent of the Christian traditions' presence in Russian literature differ. The church-religious genres prevailed in old Russian literature, with the topics, the narrative, and the author's image subjected to strictly literary and aesthetic etiquette. However, this system was dismounted by the 17 th century. With the church-religious genres interacting with secular fiction, Russian literature underwent novelization, expressed in the increased interest to a person's inner world and psychological motives behind his action, and in the emergence of entertaining elements and fictional characters in the works, depicting household.

One of the major channels for transmitting the Orthodox tradition was the distribution of works intended for individual pious reading. Of special interest is "The Way of a Pilgrim", the late 19th-century literary landmark of the Russian ascetic writing [4]. The third edition, edited and prepared for printing in 1884 by Theophan the Recluse (Govorov), received wide circulation in the Russian Empire. The literary classic was later complemented by Elder Macarius of Optina's (Ivanov) "A Warning to Those who Read Spiritual Paternal Books and Wish to Undergo the Intelligent Jesus Prayer" [5], describing the risks of selfassertive strive to a contemplative life.

Spiritual literature is designed to convey the sacred meaning of the Orthodox faith and its mystical practices to the masses using a comprehensible language. Surely enough, the meaning is fully covered in the liturgy, however, it requires explanation due to the lack of knowledge of the Old Church Slavonic language and the Orthodox symbols. Therefore, the Orthodox faith separates itself from the liturgical practices in order to be presented in churchreligious books without the organic connection with the ritual and behavioral communication. At the same time, the communicative features inherent in the sacred discourse are preserved, including but not limited to the formal semantic organization, the system of typical church-religious genres, the special imagery, achieved through the use of allegory, metaphor, and symbolism.

Critical reading of a literary text supposes some extent of interpretative freedom. The discovery of Christian meanings in the works of Russian writers is explained by the scholars' and philosophers' use of the expanded understanding of Christianity, assigning it a non-traditional meaning, and sometimes even attributing to Orthodoxy a non-compatible system of values. As a result, we may come across the statements that "there is a newly understood Christianity" in the later works of Leo Tolstoy, "representing a kind of spiritual ecumenism". There are also contradictory evaluations of the works of Nikolai Leskov: at one point he's declared "a genuine Christian", showing the Orthodox understanding of righteousness, and at some other point he is seen as an Old Believer, bringing together in his righteous characters the traits of the "Russian dissenters" - Molokans, Doukhobors, Shtundists (Leskov indeed didn't consider them to be sectarians) [6] [7].

Also, the characters' actions are subject to contradictory interpretations. The researchers, basing on ordinary everyday ideas about the possible and impossible, real and unreal, evaluate the characters' actions as unmotivated, exaggerated, accuse writers of deviating from the principles of realism [8]. Indeed, when a writer describes the spiritual (and not only psychological or emotional) life of a person, "the reality of God's presence", the very nature of human actions and ideas about what is possible, changes dramatically [9]. What is real for the mystically oriented consciousness, is a retreat from realism and a hyperbole for a secular science-minded individual. In this regard, some researchers propose to evaluate the reality and fiction in the literary works of a church-religious genre from the standpoint of a "spiritual realism" [10] [11], inherent to the writers, "gravitating to Orthodoxy" [12].

The significance of Russian fiction for the maintenance of the Orthodox tradition is due to its "Christocentrism" [13], preserved even in case of deviation from the letter and intent of Church sources. These deviations were sometimes quite significant. For example, the researchers point out to the substitution of holiness by morality, the disappointment in the Church and the assertion of the possibility of salvation in it in the works of Leo Tolstoy and Nikolai Leskov.

If we compare mechanically the corpus of literary texts with the Orthodox dogma, none of the fiction texts is to be considered fully consistent with the Orthodox dogma. The presence of the Christian tradition in a work of fiction may differ, so I.A. Esaulov considers it unnecessary and unacceptable to reveal the degree of the authors' piousness in a literary research [14].

Throughout its development, Russian literature has been retaining its connection with the Orthodox tradition through the use of the concepts, which verbalization took place under the influence of Christianity and its dogmas. The deviation from the canon in artistic expression is not a defining sign of the rupture of culture and literature with the Orthodox tradition. Even during its iconoclastic times, Russian fiction has retained the first-grade interest to the Christian in its essence topic of seeking the vital ultimate truth and moral ideal, putting forward the significance of a writer's personality and morality. 


\section{EXAMPLES OF TRANSFORMATION OF THE ORTHODOX SPIRITUAL TRADITION IN WESTERN CULTURE AND LITERATURE}

In contrast to Russian culture, the Western modernism led to a gap between culture and religion, paving the way for religious syncretism and subsequent religious globalization. Ecumenism is the form of the latter, the ideology of religious tolerance, affirming the need for a liberal dialogue of religions, recognizing the equality and equivalence of all faiths and spiritual practices.

This process is not totally unknown. Its roots stem from the very origin of Christianity, the first centuries of which took place under the conditions of the Roman Empire's religious syncretism, reaching its climax in the $3^{\text {rd }}-4$ th centuries.

The process of secularization, which started during the Renaissance, coinciding with the Age of Discovery, paved the way for active intercultural and interreligious communication. As a result, the early days of the 20th century in Europe saw a large-scale import of various religious systems and spiritual practices, including the exotic ones, the most popular of which was yoga. Orthodoxy wasn't on the roadside either. The increase in the popularity of Orthodox ideas in the early 20th century was facilitated by the emigration of clergy and intellectuals from Russian to Europe and America, making great efforts to publish numerous translations of Orthodox spiritual literature.

Carl Jung explained the European cravings for cultural and religious borrowings by the need of the Western spirit for a reliable ideological and psychological foundation: "the lack of spiritual orientation borders on mental anarchy, so any religious or philosophical practice is equivalent to some kind of psychological discipline; in other words, it is a method of mental hygiene" [15]. The Western desire to gain spiritual backbone was most fully satisfied by the Eastern teachings. C. Jung explained the Western popularity of yoga by the attractiveness of novelty; the charm of the unfamiliar and "half-obscure"; the clear statement of the purpose and ways of its achievement; the presence of profound and articulate philosophy; the ability to obtain controlled experience, creating the impression of "factuality", familiar to the Western intellectuals [16].

Under these circumstances, the Orthodox tradition couldn't be borrowed in its entirety. Yet the great interest caused the phenomena and forms of spiritual experience, in which the West saw "special systems, methods of mental and physical exercise, developing some unusual abilities, both physical and mental, lying on the verge of the supernatural" [17]. Among the "methods" was the Hesychast practice of the ceaseless Jesus Prayer as a special type of anthropological practice.

The perception of the Hesychast experience and ceaseless practice of the Jesus Prayer by a modernist conscious of a Westerner, aimed at the hybridization of perceived spiritual traditions, is described in J. D. Salinger's short story "Franny" and novella "Zooey", the part of the writer's Glass family cycle [18]. Salinger himself showed great interest in exotic religious teachings, having studied Zen Buddhism, Yoga, Scientology, Dianetics, and Leo Tolstoy's "Christian" ideas. Salinger's works were a cult classic in the West with the writer being the idol for the intellectual post-war generation, with spiritual gaze and the way of the West largely determined by his views.

In the first story "Franny", the main character gets into her hands the already mentioned book "The Way of a Pilgrim" (the 1911 edition, supplemented by several stories, was translated into a number of European languages and reprinted several times [19]). The person on whose behalf the narration is conducted, calls himself the wanderer. He talks about the mastering the power of "praying without ceasing", using the spiritual writings of the Hesychast Orthodox monks of the 4 th -15 th centuries, collected and translated from Greek in "Philokalia". The wanderer was guided and strengthened by the elder (the starets), experienced in spiritual affairs and explanation of the Patristic texts.

The heroine is delighted with an idea that the ceaseless Jesus Prayer "becomes self-active... and the words get synchronized with the person's heartbeats, and then you're actually praying without ceasing. Which has a really tremendous, mystical effect on your whole outlook". Franny refers to the repetition of the Jesus Prayer by analogy with the meditative experience of the Eastern spiritual practices. This is evidenced by the constant analogy between the ceaseless Jesus Prayer and the practices of chanting God's name in other religious traditions; belief in the automatism of the prayer; the wanderer's attitude toward the elder as to the "dedicated one"; Franny's falling into trance after independent "experience" of the prayer. Step by step, Salinger leads a reader to the conclusion about the commonality of all spiritual practices. The Christological content of the Jesus Prayer gets ignored, its repetition is attributed to a mechanical effect; it is regarded as a universal experience, suitable for everyone, not only Orthodox or Christians.

In Christianity, the Word is sacred in all the richness of its semantic connotations. Theophan the Recluse warned: "the Jesus Prayer, formulated mechanically, gives nothing, like any other prayer, spoken just by the tongue. When internalizing the Jesus Prayer, imagine the Lord Himself by you, hearing your soul. ... Cry out to Him, mentally visible before yourself: "Lord Jesus Christ, Son of God, have mercy on me, a sinner". ... It is not in the words, but in the feelings for the Lord" [20].

The Buddhist spiritual practice is different: a person, chanting a mantra, doesn't understand the language in which it is pronounced since a mantra is a sound vibration, a set of sounds whose translation was lost. The meditator is only required to pronounce a mantra with the correct intonation. The sacred power is attributed to intonation, creating a person's religious mood.

In the 20th century, the Europeans showed an amazing "omnivorous" in the consumption of religious teachings, attracted to the "free market" of spiritual practices. Such freedom, on the one hand, required the elimination of any barriers and filters preventing the cultural and religious 
exports, yet on the other hand, it led to an unprecedented mixture of practices and meanings with none of the spiritual traditions having a chance for a full reproduction. Borrowed spiritual practices, isolated from their culture of origin, transformed and blended into a syncretic Weltanschauung. Besides, this ideological eclecticism jeopardized the West's own national and religious traditions. As the traditions have ceased to substantiate and determine human life and society, religious syncretism continues its growth and hardening [21].

\section{CONCLUSION}

The transmission of the religious tradition is carried out in a complex way and includes not only the doctrinal content but the related context as well. The interaction of the Orthodox tradition with other cultural spheres - secular or other religious - opens up a space for new interpretations that distort the sacred elements and spiritual experience. Literature plays a decisive role in both maintaining the traditional cultural context and its transformation. A writer describes a religious practice with its symbolic values and at the same time individualizes it through the character traits. The writer's gaze dissects religious traditions in accordance with his moral guidelines, values and the state of mind.

A distinctive feature of Russian literature is its organic connection with the Orthodox tradition, which is reflected in the extensive use of the basic Orthodox concepts. By complementing these concepts with new meanings and connotations, literature, in turn, makes a significant contribution to the reproduction of the traditional Orthodox cultural context.

\section{REFERENCES}

[1] G.V. Kalitkina, Transmission of the Tradition in a Dialect Discourse // Library of "Rusin" Journal. 2015, №3. P. 167.

[2] K.A. Kuzmina, Structural and Linguistic Features of a Sermon as a Speech Genre. Candidate of Philology Thesis. SPb, 2006

[3] V.A Sotkov, The Phenomenon of Righteousness in the Works of I.S. Shmelyov in the 1920s-1930s. Candidate of Philology Thesis. Saransk, 2017. C. 3

[4] The Way of a Pilgrim. M.: Izdatelstvo "DAR", 2013. $280 \mathrm{p}$.

[5] Elder Macarius of Optina, A Warning to Those who Read Spiritual Paternal Books and Wish to Undergo the Intelligent Jesus Prayer. M.: Cortyard of Trinity Lavra of St. Sergius, 1997. 28 p.

[6] T.B. Ilinskaya, Russian Dissent in the Works of N.S. Leskov. SPb: Nevsky Institute of Language and Culture, 2010. 252 P.

[7] T.B. Ilinskaya, Molokans in the Works of N.S. Leskov // SPbGU Bulletin. 2010. Series 9. №2. P. 31-39.

[8] E.N. Kupreyanova, Leo Tolstoy's Aestetics. M., L.: Nauka, 1966. P. 286.

[9] A.M. Lyubomudrov, On Ortodoxy and Ecclesiastical Literature // Russian Literature. 2001. № 1. P. 123-124.

[10] A.M. Lyubomudrov, Spiritual Realism as a reflection of Religious Culture in Fiction // Bulletin of Slavic Cultures. 2008. № 1-2(9). P. 113-120.

[11] A.A. Alekseev, Sources of Spiritual Realism in Russian Classical Literature // Classical Literature and Religious Discourse (Problems of Axiology and Poetics): Collection of Academic Writing Ekaterinburg: Ural University Publishing House, 2007. P. 223-234

[12] Ibid. P. 223
[13] V.A. Sotkov The Phenomenon of Righteousness in the Works of I.S. Shmelyov in the 1920s 1930s. P. 3

[14] I.A. Esaulov, Russian Classics: a New Understanding. St. Petersburg. Aleteya, 2012. $448 \mathrm{p}$

[15] C. Jung, Archetype and Symbol. Yoga in the West. URL: https://gtmarket.ru/laboratory/basis/4229/4235 (accessed on 15.03.2018).

[16] Ibid.

[17] S.S. Horuzhiy, Experiments from the Russian Spiritual Tradition. M.: St. Thomas Institute, 2018. P. 7

[18] J.D. Salinger. Franny and Zooey. M.: Eksmo, SPb,: Domino, 2009. $256 \mathrm{p}$.

[19] N.S. Ipatova, N.S. Leskov and "The Way of a Pilgrim" // Pushkin Readings. 2014. P. 89.

[20] Theophan the Recluse. Letters. Publication 1-8. 1338. On the Proper Formulation of the Jesus Prayer and Its Fruits. URL: http://www.biblioteka3.ru/biblioteka/feof zatv/pisma8/txt05.html (accessed on 08.03.2018).

[21] K. Johnson, The Jesus Prayer in the Orthodox Tradition and Its Borrowing Outside of Orthodoxy // Diogenes' Lantern. Man in a Variety of Practices. 2015. № 1. P. 162. 